\title{
Evaluation of the Social Benefits of Financial Innovation Towns Based on SEM Model_-Taking Yuhuang Shannan Fund Town as an Example
}

\author{
Guimei $\mathrm{Wu}^{1, \mathrm{a}^{*}}$, Yuting $\mathrm{Ye}^{1, \mathrm{~b}}$, Ting $\mathrm{Li}^{1, \mathrm{c}}$, Xueqin $\mathrm{Chen}^{2, \mathrm{~d}}$, and Shasha Zhu ${ }^{1, \mathrm{e}}$ \\ ${ }^{1}$ South-Central University for Nationalities, School of Economics, Hongshan, Wuhan, China \\ ${ }^{2}$ South-Central University for Nationalities, School of Mathematics and Statistics, Hongshan, Wuhan, China
}

\begin{abstract}
Taking Yuhuang Shannan Fund Town as a typical example, this paper established a financial innovation characteristic town social benefit evaluation system through on-site investigation and quantitative analysis. It can be summarized into five major aspects: social and livelihood development, socioeconomic development, ecological environment, infrastructure construction and related system construction. Then we constructed a structural equation model (SEM) for the evaluation of social benefits of towns, and made the assumption that the impact of the five latent variables on the total variable of social benefits is positive. Through the first-order confirmatory factor analysis and the second-order confirmatory factor analysis of the structural equation, it is concluded that the five latent variables have a positively significant impact on the social benefits and have strong internal consistency. According to the degree of influence, effective suggestions are given from private equity and industrial foundation, which provide reference and practical guidance of the construction of financial innovative towns in the future.
\end{abstract}

\section{Introduction}

Financial innovation town is a new exploration to break the traditional development path of financial industry, which is represented by various financial centres, and can provide effective financial capital support for supply-side structural reform and innovation-driven development.

Literature focusing on financial innovation towns mainly explores how to build a more inclusive financial innovation town. Firstly, from the perspective of planning and construction of characteristic towns, Mengzhou Xu1 et al. proposed the key cultivating elements such as value orientation, spatial environment, system structure and supporting system. Secondly, from the perspective of evaluation and governance of financial innovation towns, Yizhou Wu2 et al. put forward an index system combining subjective and objective, qualitative and quantitative, through expert consultation: three dimensions: basic information, development performance and characteristic level.

To advance knowledge in this area and to facilitate possible development considerations in financial innovation town, this study has three main objectives. First, it takes Yuhuang Shannan Fund Town as an example, this study selects, optimizes and establishes the social benefit evaluation index of the project of this town, and then constructs the social benefit evaluation model of the project of it based on SEM. Second, based on SEM, empirical research is conducted on the social benefit evaluation of this town projects. Third, according to the influence degree of various factors in the model, the study puts forward some suggestions for the construction of this town.

Hence, a significant portion of this study explores the social benefit and evaluation system of financial innovation town, while others explore the core issues of its construction and development, and provides development strategies for other financial towns.

\section{Optimization of social benefit evaluation index system}

Combined with economic theory and sociological theory, this paper constructs the social benefit evaluation index ${ }^{3}$ of fund town. The index system is determined from five aspects: socioeconomic development, social and livelihood development, ecological environment, infrastructure construction and related system construction $^{4}$. Socioeconomic development includes financial industry agglomeration degree (EC1), financial industry innovation (EC2), international conformity (EC3), industrial and financial foundation (EC4), influence in the Yangtze River Delta (EC5) and radiation effects of leading companies (EC6). Social and livelihood development includes resident employment effect (PL1), improvement of residents' living standards (PL2), cultural integration into town construction (PL3), public

\footnotetext{
"Corresponding author: ${ }^{\mathrm{a}} \mathrm{wgm18scuec@}$ foxmail.com

bYe13340046133@163.com, ${ }^{c}$ Crady12@163.com,

dbabyxqc@foxmail.com, e3116962296@foxmail.com
} 
participation (PL4) and social stability and national unity (PL5). Ecological environment includes pollution control (EE1), industrial ecological advantage (EE2) and town style and coordination (EE3). Infrastructure construction includes construction of diversified service models (IN1), sustainability of facility construction (IN2), livability of the town (IN3) and financial security construction level (IN4). Related system construction includes enterprise talent admission system (SY1), environmental protection system (SY2), adaptability to society (SY3), foreign investment policy (SY4), government investment (SY5) and government policy innovation (SY6).

\subsection{Reliability analysis}

In order to make the results more credible, the article chooses Cronbach's $\alpha \geq 0.7$ as the index retention standard. When the coefficient is less than 0.7 , the indicator will be modified or deleted. Bring the collected data into the software SPSS20.0 to calculate ${ }^{5}$ the Cronbach's $\alpha \geq 0.7$ coefficient of each evaluation item.

Table1. Reliability analysis of variables

\begin{tabular}{|c|c|c|}
\hline Items & Number of items & Cronbach's $\alpha$ \\
\hline $\begin{array}{c}\text { Socioeconomic } \\
\text { development }\end{array}$ & 6 & 0.835 \\
\hline $\begin{array}{c}\text { Social and } \\
\text { livelihood } \\
\text { development }\end{array}$ & 5 & 0.785 \\
\hline $\begin{array}{c}\text { Ecological } \\
\text { environment }\end{array}$ & 3 & 0.736 \\
\hline $\begin{array}{c}\text { Infrastructure } \\
\text { construction }\end{array}$ & 4 & 0.807 \\
\hline $\begin{array}{c}\text { Related system } \\
\text { construction }\end{array}$ & 6 & 0.853 \\
\hline Total & 24 & 0.807 \\
\hline
\end{tabular}

\subsection{Validity analysis}

The KMO value and the Bartlett sphere test are used for the validity test, and the questionnaire has structural validity when the significance probability $P$ value of the chi-square statistical value of the Bartlett sphere test is less than $0.05 ; \mathrm{KMO} \geq 0.6$ is used as the criterion for index retention. When $\mathrm{KMO}<0.6$, the indicator will be modified or deleted. Use software SPSS20.0 to calculate the KMO value of each evaluation item ${ }^{6}$.

Table2. Modified KMO value and Bartlett sphericity test

\begin{tabular}{|c|c|c|c|}
\hline Items & $\begin{array}{c}\text { Sampling } \\
\text { Adequacy KMO } \\
\text { Measurement }\end{array}$ & $\begin{array}{c}\text { Approximate } \\
\text { chi-square }\end{array}$ & df \\
\hline $\begin{array}{c}\text { Socioeconomic } \\
\text { development }\end{array}$ & 0.826 & 143.374 & 15 \\
\hline $\begin{array}{c}\text { Social and } \\
\text { livelihood } \\
\text { development }\end{array}$ & 0.751 & 105.608 & 15 \\
\hline $\begin{array}{c}\text { Ecological } \\
\text { environment }\end{array}$ & 0.787 & 57.896 & 6 \\
\hline
\end{tabular}

\begin{tabular}{|c|c|c|c|}
\hline $\begin{array}{c}\text { Infrastructure } \\
\text { construction }\end{array}$ & 0.684 & 136.716 & 10 \\
\hline $\begin{array}{c}\text { Related system } \\
\text { construction }\end{array}$ & 0.828 & 185.368 & 28 \\
\hline
\end{tabular}

\section{SEM empirical research}

\subsection{First-order confirmatory factor analysis}

After the above calculations, we test the hypothesis of the relationship between the various latent variables proposed above, and obtain the standardized model of the firstorder confirmatory factor analysis of the structural model after using the AMOS20 calculation.

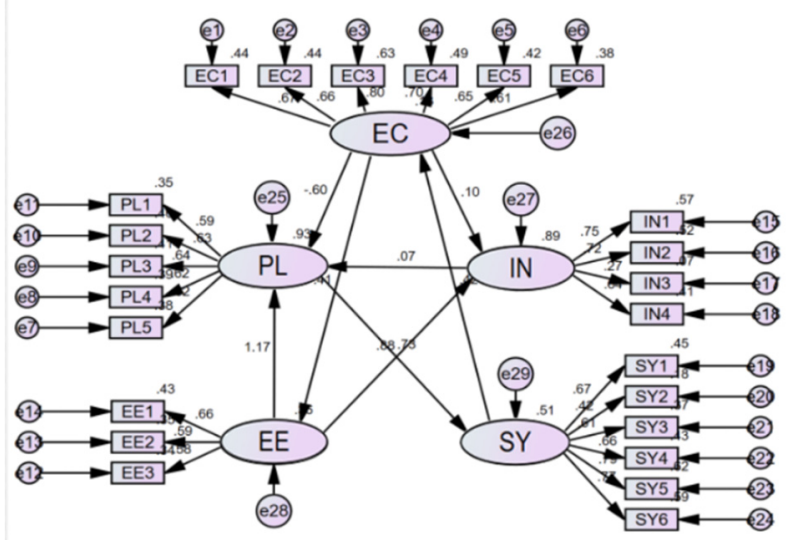

Fig 1. First-order confirmatory factor analysis

As can be seen from the above figure, The $\mathrm{P}$ value of socioeconomic development's impact on the ecological environment, socioeconomic development on infrastructure construction, related system construction on socioeconomic development, infrastructure construction on social and people's livelihood development, and Ecological environment on social and people's livelihood development have $\mathrm{P}$ values greater than 0.05 , so the relationship between these latent variables is not obvious, and the above paths need to be deleted.

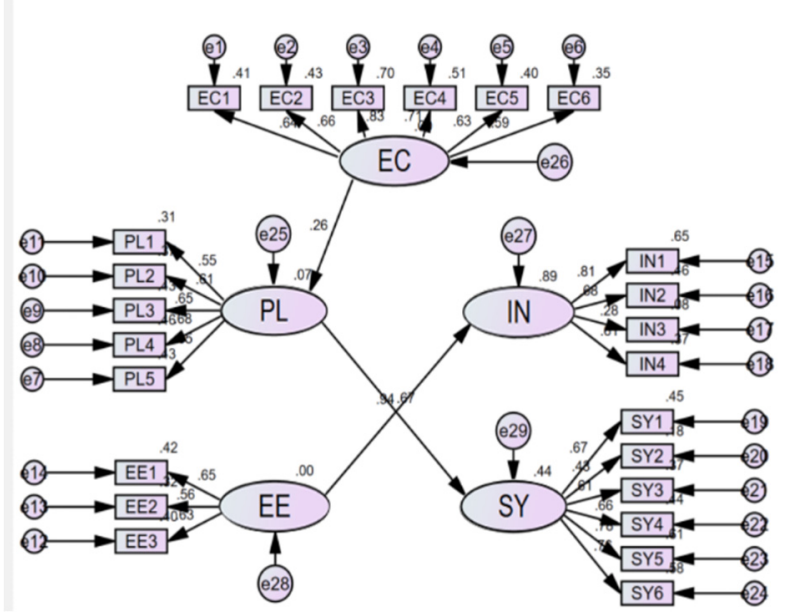

Fig 2. First-order confirmatory factor analysis after deleting the path 


\subsection{Second-order confirmatory factor analysis}

On the basis of the above-mentioned first-order verification, it is necessary to further verify the path coefficients of 5 latent variables to the social benefits of characteristic towns, a higher-order variable. After running through AMOS20, the following chart is obtained:

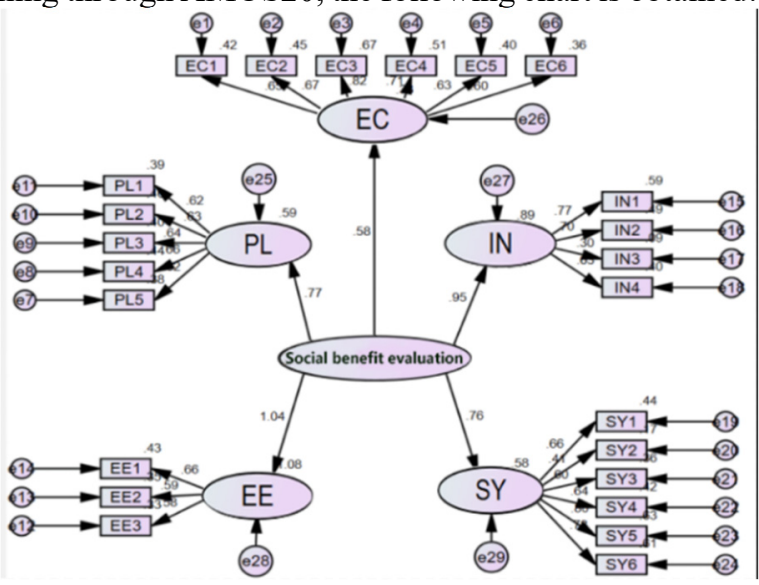

Fig 3. The second-order confirmatory factor analysis model of the structural model

It can be seen from the figure that the path coefficient $\beta=1.04>1$ for the evaluation of the social effect of the town on the ecological environment, this path needs to be revised. After trying, the path of Ecological environment $\rightarrow$ EE2 (town pollution and governance) is deleted., The modified path diagram and parameter estimation table are as follows.

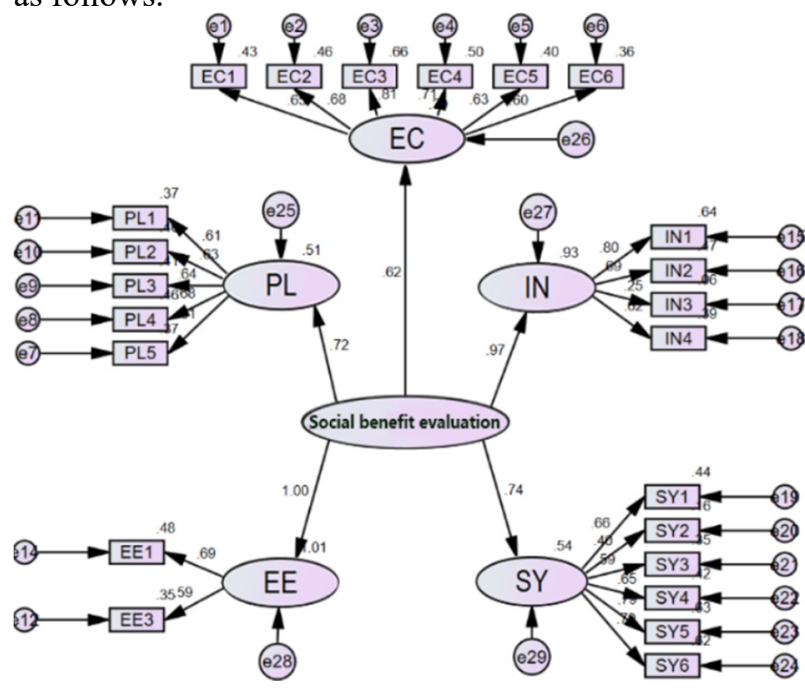

Fig 4. The second-order confirmatory factor analysis model of the structural model after deleting the path

RMSEA

\begin{tabular}{|l|rrrr} 
Model & RMSEA & LO 90 & HI 90 & PCLOSE \\
Independence model & .065 & .043 & .084 & .115
\end{tabular}

RMSEA is between 0.05 and 0.08 , indicating that the model is within an acceptable range; when RMSEA is less than 0.05 , it indicates that the model fits well. From this standard, it can be seen that the fit of the model is acceptable.

\subsection{Analysis of the social benefit evaluation conclusion}

Table3. Path coefficient between variables

\begin{tabular}{|l|c|l|c|}
\hline $\begin{array}{c}\text { Social and } \\
\text { livelihood } \\
\text { development }\end{array}$ & $<---$ & $\begin{array}{c}\text { Socioeconomic } \\
\text { development }\end{array}$ & 0.26 \\
\hline $\begin{array}{c}\text { Ecological } \\
\text { environment }\end{array}$ & $<--$ & $\begin{array}{c}\text { Socioeconomic } \\
\text { development }\end{array}$ & 0.41 \\
\hline $\begin{array}{c}\text { Infrastructure } \\
\text { construction }\end{array}$ & $<---$ & $\begin{array}{c}\text { Socioeconomic } \\
\text { development }\end{array}$ & 0.10 \\
\hline $\begin{array}{l}\text { Related system } \\
\text { construction }\end{array}$ & $<---$ & $\begin{array}{l}\text { Social and } \\
\text { livelihood } \\
\text { development }\end{array}$ & 0.94 \\
\hline $\begin{array}{l}\text { Social and } \\
\text { livelihood } \\
\text { development }\end{array}$ & $<---$ & $\begin{array}{l}\text { Ecological } \\
\text { environment }\end{array}$ & 1.17 \\
\hline $\begin{array}{l}\text { Social and } \\
\text { livelihood } \\
\text { development }\end{array}$ & $<---$ & $\begin{array}{l}\text { Infrastructure } \\
\text { construction }\end{array}$ & 0.07 \\
\hline $\begin{array}{l}\text { Infrastructure } \\
\text { construction }\end{array}$ & $<---$ & $\begin{array}{l}\text { Ecological } \\
\text { environment }\end{array}$ & 0.67 \\
\hline $\begin{array}{l}\text { Socioeconomic } \\
\text { development }\end{array}$ & $<--$ & $\begin{array}{l}\text { Related system } \\
\text { construction }\end{array}$ & 0.48 \\
\hline
\end{tabular}

The path coefficient of social and livelihood development on system construction is 0.94 , which has a significant impact; the path coefficient of ecological environment on infrastructure is 0.67 , which has a significant impact; the path coefficient of system construction on economic development is 0.48 , which has a significant impact.

Table4. Path analysis of second-order factors

\begin{tabular}{|l|r|c|}
\hline $\begin{array}{l}\text { Socioeconomic } \\
\text { development }\end{array}$ & $\begin{array}{r}\text { Evaluation } \\
\text { of social benefits of } \\
\text { characteristic towns }\end{array}$ & 0.62 \\
\hline $\begin{array}{l}\text { Social and } \\
\text { livelihood } \\
\text { development }\end{array}$ & $\begin{array}{r}\text { Evaluation } \\
\text { of social benefits of } \\
\text { characteristic towns }\end{array}$ & 0.72 \\
\hline $\begin{array}{l}\text { Infrastructure } \\
\text { construction }\end{array}$ & $\begin{array}{r}\text { Evaluation } \\
\text { of social benefits of } \\
\text { characteristic towns }\end{array}$ & 0.97 \\
\hline $\begin{array}{l}\text { Related system } \\
\text { construction }\end{array}$ & $\begin{array}{l}\text { Evaluation } \\
\text { of social benefits of } \\
\text { characteristic towns }\end{array}$ & 0.74 \\
\hline $\begin{array}{l}\text { Ecological } \\
\text { environment }\end{array}$ & $\begin{array}{l}\text { Evaluation } \\
\text { of social benefits of } \\
\text { characteristic towns }\end{array}$ & 1.00 \\
\hline
\end{tabular}

In the second-order factor analysis, the order of path coefficients is ecological environment, infrastructure construction, related system construction, social and livelihood development and socioeconomic development. These five latent variables should first consider the ecological environment and infrastructure in the social benefits, and secondly focus on social people's livelihood and system construction, and socioeconomic development also needs to be considered. The response degree of the indicator to the latent variable is represented by the path coefficient The index and their factor load are followed. EC1 equals 0.65 . EC2 equals 0.68 . EC3 equals 0.81 . EC4 equals 0.71. EC5 equals 0.63. EC6 equals 0.60. PL1 equals 0.61 . PL2 equals 0.63 . PL3 equals 0.64 . PL4 
equals 0.68. PL5 equals 0.61. EE1 equals 0.63. EE2 equals 0.69 . EE3 equals 0.59 . IN1 equals 0.80 . IN2 equals 0.69 . IN3 equals 0.25 . IN4 equals 0.62 . SY1 equals 0.66 . SY2 equals 0.40 . SY3 equals 0.59 . SY4 equals 0.65 . SY5 equals 0.73 . SY6 equals 0.79 .

Among the various indicators of socioeconomic development, the most influential ones are international conformity and the industrial foundation and financial foundation. The path coefficient is greater than 0.7, indicating that the degree of international integration and the financial industry in the social benefits of characteristic towns have a great impact on it. The innovation and concentration of the financial industry should also be considered.

From the perspective of social and livelihood development, the path coefficients are all greater than 0.6 , and the most influential one is the degree of public participation, indicating that it is essential for enterprises and residents to actively participate in the construction of small towns.

Among the various indicators of ecological environment, the industrial ecological advantage has the greatest impact, with a path coefficient of 0.69 , indicating that it is important to optimize the industrial structure of the town. The path coefficient for the coordination of town style is 0.59 , which has a significant impact, which also reflects the emphasis on the inherent cultural sentiment and the expectation of the town's coordination and consistency.

In infrastructure construction, the path coefficient of the construction level of the diversified service model is 0.8 , indicating that the town should develop diversified businesses, which is consistent with the establishment of companies in various fields in the town. The degree of financial security construction and the sustainable degree of facility construction should also be paid attention to.

In the construction of related systems, the path coefficients of government policy innovation and government capital investment are both greater than 0.7 , indicating that the government's role in the town should not be underestimated. The state plays a pivotal role in improving the social benefits of small towns. At the same time, the small town's foreign investment policy is also the key to income generation and profit, and it also plays an important role in the social benefits of the town.

\section{Conclusions and countermeasures}

On the basis of previous literatures, this paper sets up the evaluation system of social benefit of financial innovation town by literature review and investigation. The SEM model is demonstrated and the influence of the five latent variables on the social benefits is obtained.

Compared with economic growth, ecological environment and infrastructure construction are more important for the development of financial innovative towns. These results not only reveal the unbalanced development of financial innovation town, but also suggest the need for significant adjustments in all aspects. The heterogeneity of these factors also means that focusing on economic growth alone would fail the course of financial innovation town in the long run.

While most of the current literature positions economic growth at the center, this paper bridges current scholarship centered on social benefits to social's real needs considering the full range of factors, instead of single factor. The application of SEM makes the qualitative index quantized, which reflects the practicability of the evaluation system and provides a good reference in the future.

Although the scenarios are limited by available data and literature, the following three main countermeasures can be drawn from the study.

\subsection{Real economy is the financial foundation}

The primary task of finance is to lay a solid foundation for the real economy, guide financial companies to better serve the real economy, and promote the transformation and upgrading of the industrial structure. However, in the current environment of slowdown in industrial growth and continuous financial bubbles, although the stock capital market has released a good signal, the difficulty of fundraising is still unavoidable. The industry is currently in a dilemma of difficulty in investment and exit ${ }^{7}$, and the factors of valuation bias and risk asymmetry are not conducive to the healthy development of the industry.

Most of the enterprise are mainly invested in the lead investment mode, and the main industries covering Internet marketing, auto finance, auto advertising and so on. Yuhuang Shannan Fund Town can learn from foreign countries and actively explore new investment models: focus on enterprise industry chain investment, combine state-owned assets with management companies, and create the concept of "double GDP"8.

Therefore, it is recommended to build an evaluation team to fully understand the state-owned enterprises' views on specific project investment, and realize fund docking for some specific projects ${ }^{9}$, to guide companies in Yuhuang Shannan Found Town and to drive the trend.

\subsection{Play the role of private equity}

At present, the structure of equity and debt in China is unbalanced. In enterprise financing, the creditor's rights dominated by banks are greater than the equity invested by funds. This point should be changed actively so that scientific and technological innovation can develop scientifically and sustainably.

In the process of raising funds from financial institutions such as insurance banks and social security, many venture capital funds stated that compared with other types of funds such as banks ${ }^{10}$, they have low overall costs, large capital scales and long investment periods. Their government hopes that state-owned capital can be invested in private equity funds to serve the innovation of medium-sized enterprises. For example, in the process of integration in the Yangtze River Delta, the enterprises in the town can take the lead to set up the parent fund to invest in the private equity fund and evaluate third-party 
private equity fund, so as to improve the overall comprehensive ability of fund-raising. ${ }^{11}$

Through the small cut of "playing the role of private equity", we can further explore the reform causes behind the structural imbalance in the development of stock and debt in China, and provide a new value direction for the in-depth reform of multi-level capital market and the reform of mixed ownership.

\subsection{Ecological beauty and infrastructure improvement}

The construction of financial innovative town should pay attention to the coordination with the surrounding environment, so as to give foreign businessmen an excellent visual feeling. The Management Committee of the town should use natural resources sparingly to avoid waste, enhance the construction of characteristic landscape and highlight the cultural connotation.

At the same time, infrastructure construction should not only support industries, but also pay attention to public opinion and the construction of smart communities, and increase the application of new technologies. At present, with the rapid development of big data, cloud computing and other information technology, making money online has become a popular trend. In the infrastructure construction of financial innovative town, we should first attach importance to the optimization of living environment and improve the coverage rate of green buildings, so as to achieve sustainable development.

Therefore, a project management company with relevant qualifications can be hired for professional management. From the perspective of government purchasing professional services, the construction level of basic supporting facilities will be raised.

\section{References}

1. Xu, M., Wang, Z. (2016) Cultivation strategy of characteristic town from the perspective of innovation ecosystem -- a case study of dream town. J ZJ Pty Sch CPC., 33: 35-36.

2. Wu, Y., Chen, Q., Zhen, X. (2016) Indices system and evaluation method of characteristic town development. Planners., 123: 124-125.

3. Zhao, H., Wang, Y., Zhang, X., Ma, S. (2019) Financing risk assessment of PPP projects in characteristic towns based on cloud model. J Civ Eng Manag, 36:83-84.

4. Cao, Z. (2019) Interpretation of GB/T 3533.2-2017 Standardization Benefit Evaluation Part 2: General Rules for Social Benefit Evaluation. Std Qlty Mach Ind, 08:19-22.

5. Zhou, J. (2017) Questionnaire data analysis: six analysis ideas for cracking SPSS. Publishing House of Electronics Industry, Beijing.

6. Eisinga, R., Grotenhuis, M. T., Pelzer, B.(2013) The reliability of a two-item scale: pearson, cronbach, or spearman-brown?. INT J PUBLIC HEALTH, 58:638-640
7. Fan, J., Cao, S. (2019) Thoughts on the evaluation and assessment of the social benefits of book publishing units. Sci-Tech\& Public, 07:6-11.

8. Lin, C. (2019) Thoughts on the construction of the benefit evaluation and assessment mechanism of the Science and Technology Press [N]. China Pub M Biz D, Beijing.

9. Yu, M. (2019) Analysis of the development path of financial town. Financial Theory and Teaching, 02: 17-21.

10. Qin, Y., Zhang Q., Sun Z., Chen K., Qin H. (2017) Research on the construction and development of financial towns. Chn Manag IT, 20:202-203.

11. Sun, X., Bao, H., Liu Y. (2016) Financial town: the innovative development of financial agglomeration model. J ZJ Pty Sch CPC, 32:80-84. 